\title{
Pengaruh Kepemimpinan Transformasional Dan Lingkungan Kerja Terhadap Semangat Kerja Dengan Mediasi Komitmen Organisasi Karyawan Usaha Tape Di Kabupaten Bondowoso
}

\author{
Pawestri Winahyu dan Dwi Tafinia Nurhasanah \\ Fakultas EkonomiUniversitas Muhammadiyah Jember \\ Email: pawestri@unmuhjember.ac.id
}

\begin{abstract}
ABSTRAK
Penelitian ini bertujuan untuk mengetahui pengaruh Kepemimpinan Transformasional Dan Lingkungan Kerja Terhadap Semangat Kerja Dengan Mediasi Komitmen Organisasi Karyawan Usaha Tape di Kabupaten Bondowoso. Sampel yang akan digunakan dalam penelitian adalah 45 karyawan. Metode analisis data yang digunakan dalam penelitian ini yakni menggunakan uji instrumen, uji asumsi klasik, analisis jalur (path analysis) dan uji hipotesis. Hasil penelitian menunjukkan bahwa kepemimpinan transformasional dan lingkungan kerja berpengaruh signifikan terhadap komitmen organisasi, dan kepemimpinan transformasional, lingkungan kerja dan komitmen organisasi berpengaruh signifikan terhadap semangat kerja.
\end{abstract}

Kata Kunci: kepemimpinan transformasional, lingkungan kerja, semangat kerja, komitmen organisasi

\begin{abstract}
This study aims to determine the effect of Transformational Leadership and Work Environment on Work Spirit with Organizational Commitment Mediation of Tape Business Employees in Bondowoso Regency. The sample to be used in the study was 45 employees. The data analysis method used in this study is using the test instrument, classic assumption test, path analysis (path analysis) and hypothesis testing. The results showed that transformational leadership and work environment had a significant effect on organizational commitment, and transformational leadership, work environment, and organizational commitment had a significant effect on morale.
\end{abstract}

Keywords: transformational leadership, work environment, work spirit, organizational commitment

\section{PENDAHULUAN}

Komitmen organisasi merupakan sifat hubungan antara individu dengan komitmen kerja, dimana individu mempunyai keyakinan diri terhadap nilai-nilai dan tujuan komitmen kerja, adanya kerelaan untuk menggunakan usahanya secara sungguhsungguh demi kepentingan komitmen kerja serta mempunyai keinginan yang kuat untuk tetap menjadi bagian dari komitmen kerja. Dalam hal ini individu mengidentifikasikan dirinya pada suatu komitmen tertentu tempat individu bekerja dan berharap untuk menjadi anggota komitmen kerja guna turut merealisasikan tujuan-tujuan komitmen kerja (Kuntjoro, 2009). 
Sumber daya manusia sangat menentukan keberhasilan atau ketidakberhasilan suatu organisasi. Motivasi yang kuat dalam bekerja terjadi jika ada kesesuaian atau keselarasan antara karyawan dengan ciri-ciri pekerjaan. Karyawan adalah asset (kekayaan) utama setiap perusahaan, yang selalu ikut aktif berperan dan paling menentukan tercapai tidaknya tujuan perusahaan (Hasibuan, 2013). Oleh karena itu perusahaan harus memiliki karyawan untuk mencapai tujuannya, untuk melaksanakan fungsi-fungsi dalam sebuah organisasi di dalam perusahaan. Serta memberikan hasil kinerja yang menguntungkan bagi perusahaan.

Sumber daya manusia merupakan faktor penting dalam sebuah organisasi. Manusia memiliki kemampuan untuk menggerakkan semua sumber daya yang ada. Tanpa adanya sumber daya manusia yang baik, perusahaan akan sulit berkembang. Kekuatan setiap perusahaan atau organisasi adalah terletak pada SDM yang mengelola dan menanganinya apabila SDM diperhatikan secara tepat dengan menghargai bakatbakat, untuk mengembangkan kemampuan, menggunakannya secara tepat maka perusahaan atau organisasi akan menjadi dinamis dan berkembang serta adanya peningkatan produktivitas (Galih dan Azis: 2017).

Semangat kerja merupakan indikator yang sangat penting bagi setiap karyawan untuk menyelesaikan tugas-tugas dari pekerjaannya. Menurut Nitisemito (2014) semangat kerja adalah melakukan pekerjaan lebih giat sehingga dengan demikian pekerjaannya akan lebih dapat diharapkan selesai lebih cepat dan lebih baik dengan adanya semangat kerja pada diri setiap karyawan. Bagi suatu organisasi meningkatkan semangat kerja pegawai merupakan unsur penting yang akan mempengaruhi prestasi organisasi, sebab dengan semangat kerja diharapkan semua aturan ditaati oleh seluruh pegawai selain itu dengan semangat kerja akan memperoleh banyak keuntungan dalam pencapaian tujuan organisasi akan tercapai secara efektif dan efisien seperti pekerjaan akan lebih cepat diselesaikan, kerusakan akan dapat dikurangi, absensi dapat diperkecil dan produktivitas kerja akan meningkat. Dengan demikian apabila semangat kerja menurun maka tujuan organisasi yang telah ditetapkan oleh suatu organisasi tidak dapat tercapai, dan dengan semangat kerja diharapkan dapat menciptakan keteraturan dalam upaya membuahkan hasil kerja yang optimal (Mardani: 2013).

Penelitian tentang semangat kerja dan komitmen organisasi telah dilakukan oleh peneliti-peneliti sebelumnya. Hasil dari penelitian sebelumnya terdapat beberapa hal penting yang dapat dijadikan dasar perbandingan serta acuan dalam penelitian ini. Penelitian terdahulu yang menjadi acuan dalam penelitian ini yang menjelaskan tentang keputusan pembelian diantaranya Larasati (2014), Kesuma dan Supartha (2016), Salahudin (2013), Tamara (2016) dan Fane (2016).

Penelitian yang dilakukan oleh Larasati (2014), variabel bebas yaitu; Kharisma (X1), Inspiration (X2), Stimulasi, Intelektual (X3), Perhatian yang diindividualisasi (X4), variabel terikat yaitu; Semangat Kerja (Y). Sampel yang digunakan sebanyak 45 karyawan. Alat anaisis yang digunakan adalah analisis regeresi linier berganda. Hasil pengujian menerangkan bahwa Kharisma, inspiration, stimulasi intelektual, dan perhatian yang diindividualisasi berpengaruh signifikan terhadap semangat kerja.

Penelitian yang dilakukan oleh Kesuma dan Supartha (2016), variabel bebas yaitu; Kepemimpinan transformasional (X1), variabel terikat yaitu; Kepuasan kerja (Y1), OCB (Y2), Komitmen organisasi (Y3), populasi yang digunakan adalah seluruh karyawan tetap (PNS), karyawan pramubakti (Honorer) dan Satuan Pengamanan kantor KPTIK-BMN Denpasar. Hasil pengujian menerangkan bahwa kepemimpinan tranformasional berpengaruh positif dan signifikan terhadap OCB, kepemimpinan tranformasional berpengaruh positif terhadap kepuasan kerja, kepemimpinan 
tranformasional berpengaruh positif terhadap komitmen organisasional, kepuasan kerja berpengaruh positif terhadap komitmen organisasional, OCB berpengaruh positif terhadap komitmen organisasional organisasional.

Penelitian yang dilakukan oleh Salahudin (2013). Variabel bebas yaitu; Kepemimpinan (X1) Lingkungan Kerja (X2), variabel terikat yaitu; Komitmen organisasiona (Y1) Lingkungan Kerja (Y2) Kinerja Karyawan (Y3). Sampel yang digunakan sebanyak 120 karyawan. Hasil pengujian menerangkan bahwa Kepemimpinan berpengaruh signifikan terhadap Komitmen Organisasional karyawan, Lingkungan Kerja berpengaruh signifikan terhadap Komitmen Organisasional karyawan, Kepemimpinan berpengaruh tidak signifikan terhadap Kinerja Karyawan, Lingkungan kerja berpengaruh tidak signifikan terhadap kinerja karyawan, Komitmen organisasional berpengaruh tidak signifikan terhadap kinerja karyawan, kepemimpinan berpengaruh tidak langsung terhadap kinerja karyawan.

Penelitian yang dilakukan oleh Tamara (2016) variabel bebas yaitu; Lingkungan Kerja Fisik (X1) Lingkungan Kerja Psikis (X2), variabel intervening yaitu: Kepuasan Kerja (Z), variabel terikat yaitu; Semangat Kerja (Y) Sampel yang digunakan sebanyak 57 karyawan. Hasil pengujian menerangkan bahwa Lingkungan kerja fisik, lingkungan kerja psikis, dan kepuasan kerja berpengaruh signifikan terhadap semangat kerja.

Penelitian yang dilakukan oleh Fane (2016) variabel bebas yaitu: Komitmen Organisasi (X1), Motivasi Kerja (X2), variabel terikat yaitu: Semangat Kerja (Y1). Hasil penelitian diperoleh variabel komitmen organisasi dan motivasi kerja berpengaruh signifikan terhadap semangat kerja karyawan CV. Tunas Pratama Palembang.

Kabupaten Bondowoso merupakan Kabupaten yang memiliki brand sebagai Kota Tape yang memiliki kualitas yang berbeda dibandingkan dengan daerah lain. Kabupaten Bondowoso merupakan salah satu daerah di Jawa Timur yang terkenal dengan produk makanan olahan berbahan dasar ubi kayu atau singkong. Makanan olahan yang dihasilkan antara lain tape, proll tape, keripik singkong, brownies tape, suwar-suwir, dan dodol tape. Produk olahan ubi kayu yang paling terkenal adalah tape singkong sehingga Bondowoso lebih dikenal sebagai kota tape.

Produksi tape ini juga bersaing antara produsen yang satu dengan yang lain. Persaingan yang terjadi mengakibatkan setiap industri terus menerus untuk menawarkan produknya yang terbaik, entah itu dengan mengeluarkan produk baru seperti tape tanpa serat atau hanya dengan merubah kemasan dari besek menjadi dos. Namun kondisi saat ini pemiliki usaha tape dilanda penurunan tingkat penjualan. Hal ini dikarena adanya pesaing oleh-oleh lainnya yang lebih kekinian sehingga tren oleh-oleh beralih. Penurunan penjualan tape berdampak negatif bagi pemilik rumah produksi tape, misalnya pengurangan jumlah karyawan. Pengurangan jumlah karyawan mengakibatkan semangat kerja karyawan menurun sehingga mereka kurang berkomitmen untuk terus bekerja pada pemilik rumah produksi tape. Kepemimpinan pemilik rumah produksi tape yang mampu memberikan arahan kepada karyawan akan menciptakan lingkungan kerja yang cukup stabil meskipun rumah produksi tape sedang dilanda musim paceklik. Adapun rumusan masalah dalam penelitian ini adalah :

1. Apakah kepemimpinan transformasional berpengaruh signifikan terhadap komitmen organisasi karyawan pada Usaha Tape di Kabupaten Bondowoso?

2. Apakah lingkungan kerja berpengaruh signifikan terhadap komitmen organisasi pada Usaha Tape di Kabupaten Bondowoso?

3. Apakah kepemimpinan transformasional berpengaruh signifikan terhadap semangat kerja karyawan pada Usaha Tape di Kabupaten Bondowoso? 
4. Apakah lingkungan kerja berpengaruh signifikan terhadap semangat kerja karyawan pada Usaha Tape di Kabupaten Bondowoso?

5. Apakah komitmen organisasi berpengaruh signifikan terhadap semangat kerja karyawan pada Usaha Tape di Kabupaten Bondowoso?

Tabel 1. Produsen Tape Bondowoso

\begin{tabular}{|c|c|c|}
\hline No & Nama Produk & Alamat \\
\hline 1 & Tape 82 & $\begin{array}{l}\text { Toko: Jln PB. Sudirman } 29 \\
\text { Rumah: Brigpol. Sudarlan } 82\end{array}$ \\
\hline 2 & Tape 31 & Toko / Rumah: Jln PB. Sudirman 31 \\
\hline 3 & Tape 99 & Toko / Rumah: Jln Raya Situbondo 99 \\
\hline 4 & Tape 17 & Toko / Rumah: Jln Ahmad Yani 17 \\
\hline 5 & Tape 45 & Toko / Rumah: Jln Raya Situbondo 45 \\
\hline 6 & Tape 88 & Toko / Rumah: Jln Ahmad Yani 88 \\
\hline 7 & Tape 93 & Toko / Rumah: Jln Ahmad Yani 93 \\
\hline 8 & Tape 38 & Toko / Rumah: Jln Raya Situbondo 38 \\
\hline
\end{tabular}

9 Tape $12 \quad$ Toko / Rumah: Jln. Mangkunegara 12

Sumber: Data Sekunder diolah, 2018.

\section{TINJAUAN PUSTAKA}

\section{Kepemimpinan Transformasional}

Robbins dan Judge (2015) kepemimpinan transformasional adalah pemimpin yang memberikan pertimbangan dan rangsangan intelektual yang diindividualkan dan memiliki karisma. Menurut Danim (2004) kepemimpinan transformasional adalah kemampuan seorang pemimpin dalam bekerja dengan dan atau melalui orang lain untuk mentransformasikan, secara optimal sumber daya organisasi dalam rangka mencapai tujuan yang bermakna sesuai dengan target capaian yang telah ditetapkan.

Menurut Robbins dan Judge (2015) kepemimpinan transformasional merupakan model kepemimpinan yang mana para pemimpin menginspirasi para pengikutnya untuk melampaui kepentingan diri mereka sendiri dan yang berkemampuan untuk memiliki pengaruh secara mendalam dan luar biasa terhadap para pengikutnya. Menurut Yukl (2010) kepemimpinan transformasional sebagai sebuah proses yang padanya para pemimpin dan pengikut saling menaikkan diri ketingkat moralitas dan motivasi yang lebih tinggi. Pemimpin tersebut memotivasi para pengikut dengan cara membuat mereka lebih sadar mementingkan organisasi atau tim daripada kepentingan diri sendiri. 
Kepemimpinan transformasional menunjuk kepada proses membangun komitmen terdapat sasaran organisasi dan memberi kepercayaan kepada para pengikut untuk mencapai sasaran-sasaran tersebut (Yukl; 2010).

Definisi kepemimpinan transformasional adalah kemampuan pemimpin mengubah lingkungan kerja, motivasi kerja, dan pola kerja dan nilai-nilai kerja yang dipersepsikan bawahan sehingga mereka lebih mampu mengoptimalkan kinerja untuk mencapai tujuan organisasi (Yukl; 2010). Dari beberapa pendapat dapat disimpulkan bahwa kepemimpinan transformasional mentransformasi dan memotivasi para bawahannya dalam rangka untuk mencapai tujuan sesuai dengan target yang telah ditetapkan.

\section{Lingkungan Kerja}

Lingkungan kerja adalah kondisi-kondisi disekitar karyawan baik itu berupa kondisi materi maupun psikologis. Menurut Mardiana (2005) mengemukakan bahwa "lingkungan kerja adalah lingkungan dimana pegawai melakukan pekerjaannya seharihari”. Lingkungan kerja yang kondusif dipercaya dapat meningkatkan kinerja karyawan. Nitisemito (2014) mengemukakan "lingkungan kerja adalah segala sesuatu yang ada disekitar para pekerja yang dapat mempengaruhi dirinya dalam menjalankan tugas-tugas yang diembankan."

Lingkungan kerja yang kondusif dalam hal ini adalah meliputi keadaan fisik dan non-fisik yang dapat memberikan kesan menyenangkan, aman, tentram, perasaan betah, dan lain sebagainya. Sihombing (2004) menyatakan bahwa "lingkungan kerja adalah faktor-faktor di luar manusia baik fisik maupun no-fisik dalam suatu organisasi". Faktor fisik ini mencakup peralatan kerja, suhu tempat kerja, kesesakan dan kepadatan, kebisingan, luas ruang kerja sedangkan non-fisik mencakup hubungan kerja yang terbentuk di instasi antara atasan dan bawahan serta antara sesama karyawan.

Keselamatan diri dan barang milik karyawan dapat terpenuhi dan terjamin sehingga tidak akan ada rasa was-was ataupun khawatir. Misalnya, suatu lingkungan perusahaan tersebut kurang steril dan kurang menjaga kebersihan lingkungannya maka dampak yang ditimbulkan adalah sarang penyakit yang menimpa salah satu karyawan perusahaan tersebut, secara otomatis kualitas kinerja karyawan tersebut berkurang dan jika hal demikian terus terjadi tanpa ada solusi maka produk yang dihasilkan perusahaan tersebut menjadi semakin berkurang, ini berarti produktivitas karyawan rendah, perusahaan akan mengalami kerugian oleh karena itu karyawan dituntut untuk memiliki kapabilitas yang tinggi guna mencapai suatu produktivitas yang maksimal, perusahaan harus menjamin dipilihnya orang yang tepat serta situasi dan kondisi yang memungkinkan mereka bekerja secara optimal.

\section{Komitmen Organisasi}

Menurut Suparyadi (2015) komitmen organisasi sebagai derajat di mana karyawan percaya dan mau menerima tujuan-tujuan organisasi dan akan tetap atau tidak akan meninggalkan organisasinya. Menurut Mangkunegara (2008) komitmen kerja seorang karyawan merupakan kondisi atau energi yang menggerakkan diri karyawan yang terarah atau tertuju untuk tujuan organisasi perusahaan.

Pengertian komitmen organisasi dari berbagai sumber diatas dapat ditarik kesimpulan bahwa komitmen organisasi adalah kondisi dimana karyawan yang terarah atau tertuju untuk tujuan organisasi perusahaan serta percaya dan mau menerima tujuantujuan organisasi dan tidak akan meninggalkan organisasinya. 


\section{Semangat Kerja}

Menurut Nitisemito (2014) semangat kerja adalah melakukan pekerjaan lebih giat sehingga dengan demikian pekerjaannya akan lebih dapat diharapkan selesai lebih cepat dan lebih baik. Sedangkan menurut Azwar (2011) semangat kerja merupakan gambaran perasaan yang berhubungan dengan tabiat atau jiwa semangat kelompok, kegembiraan atau kegiatan, untuk kelompok-kelompok pekerja yang menunjukkan iklim dan suasana pekerja. Selanjtnya menurut Hasibuan (2013) mengemukakan bahwa semangat kerja adalah keinginan dan kesungguhan seorang mengerjakan pekerjaannya dengan baik serta berdisiplin untuk mencapai produktivitas yang maksimal.

Dari beberapa pendapat tersebut dapat diambil kesimpulan bahwa semangat kerja adalah tabiat individu atau kelompok untuk bekerja sama melakukan pekerjaan yang lebih giat dan sukarela serta berdisiplin untuk mencapai produktivitas yang maksimal.

\section{METODE PENELITIAN}

Berdasarkan latar belakang dan rumusan masalah yang sudah dijelaskan, maka penelitian ini dapat diklarifikasikan sebagai Explanatory Research. Menurut Hermawan (2009) "explanatory research" merupakan penelitian yang menjelaskan hubungan kausal antara variabel-variabel melalui pengujian hipotesis. Populasi dalam penelitian ini adalah seluruh karyawan yang bekerja di Usaha Tape di Kabupaten Bondowoso yaitu berjumlah 9 pemilik yang memiliki 45 karyawan. Penelitian ini menggunakan sampel jenuh atau metode sensus, yaitu teknik penentuan sampel apabila semua anggota populasi digunakan sebagai sampel. Metode pengumpulan data yang digunakan dalam penelitian ini meliputi metode suvey, studi dokumentasi dan obsevasi. Model analisis yang digunakan adalah analisis jalur (Path Analysis).

Dalam penelitian ini definisi operasional variabel akan dijelaskan mengenai variabel-variabel yang akan diamati sekaligus menjadi obyek pengamatan dalam penelitian.

\section{Kepemimpinan Transformasional (X1)}

Kepemimpinan transformasional mentransformasi dan memotivasi para bawahannya dalam rangka untuk mencapai tujuan sesuai dengan target yang telah ditetapkan. Adapun indikatornya adalah sebagai berikut:

1. Attributed Charisma, Pemimpin mendahulukan kepentingan perusahaan dan kepentingan orang lain dari kepentingan diri.

2. Inspirational Leadership/Motivation, Pemimpin mampu menimbulkan inspirasi pada bawahannya, antara lain dengan menentukan standar-standar tinggi, memberikan keyakinan bahwa tujuan dapat dicapai.

3. Intellectual Stimulation, Bawahan merasa bahwa pimpinan mendorong mereka untuk memikirkan kembali cara kerja mereka, untuk mencari cara-cara baru dalam melaksanakan tugas, mereka mendapatkan cara baru dalam mempersepsi tugas-tugas mereka,

4. Individiulized Consideration, Bawahan merasa diperhatikan dan diperlakukan secara khusus oleh pimpinannya.

5. Idealized Influence, Pemimpin berusaha melalui pembicaraan, mempengaruhi bawahan dengan menekankan pentingnya nilai-nilai dan keyakinan, pentingnya 
keikatan pada keyakinan (beliefs), perlu dimilikinya tekad mencapai tujuan, perlu diperhatikan akibat-akibat moral dan etik dari keputusan yang diambil.

\section{Lingkungan Kerja (X2)}

Menurut Sihombing (2004) lingkungan kerja fisik adalah salah satu unsur yang harus digunakan perusahaan sehingga dapat menimbulkan rasa aman, tentram, nyaman, dan dapat meningkatkan hasil kerja yang baik untuk peningkatan kinerja karyawan. Adapun indikatornya adalah sebagai berikut:

1. penerangan/cahaya di tempat kerja

2. temperature/suhu udara di tempat kerja

3. kerapihan di tempat kerja

4. kelembapan udara

5. tata warna di tempat kerja

6. dekorasi di tempat kerja

7. keamanan di tempat kerja

\section{Komitmen Organisasi (Z)}

Komitmen organisasi adalah kondisi dimana karyawan yang terarah atau tertuju untuk tujuan organisasi perusahaan serta percaya dan mau menerima tujuan-tujuan organisasi dan tidak akan meninggalkan organisasinya. Adapun indikatornya adalah sebagai berikut:

1. Faktor Personal, Karakteristik yang dimiliki oleh individu anggota organisasi atau perusahaan, seperti nilai-nilai yang dianut, kompetensi yang dimiliki, motivasi untuk menjadi anggota organisasi atau perusahaan, dan pengalaman.

2. Faktor Internal Organisasi, Faktor-faktor personal dapat dinetralisasi atau diperkuat oleh faktor-faktor internal organisasi seperti ganjaran atau kompensasi, gaya kepemimpinan, hubungan dengan dan dukungan dari rekan kerja, dan kebijakan organisasi.

3. Faktor Eksternal Organisasi, memberikan peluang untuk memenuhi kebutuhan karyawan secara lebih baik sangat mungkin dapat berengaruh pada tidak cukup kuatnya komitmen karyawan terhadap organisasinya.

Semangat Kerja (Y)

Semangat kerja adalah tabiat individu atau kelompok untuk bekerja sama melakukan pekerjaan yang lebih giat dan sukarela serta berdisiplin untuk mencapai produktivitas yang maksimal. Adapun indikatornya adalah sebagai berikut:

1. Perasaan senang dan bangga terhadap pekerjaan yang dilakukan

2. Mampu menyelesaikan pekerjaan dengan tepat waktu

3. Karyawan masuk kerja dan pulang dengan tepat waktu

4. Terampil dan kreatif

5. Memiiki motivasi yang tinggi

6. Karyawan bekerjasama dengan rekan kerja yang lainnya.

7. Karyawan bekerja sama dengan atasan.

\section{Analisis Jalur (Path Analysis)}

\section{HASIL PENELITIAN}

Sarwono dan Budiono (2012) menyatakan bahawa analisis jalur merupakan teknik analisis yang digunakan untuk menganalisis hubungan sebab akibat yang inheren antar variabel yang disusun berdasarkan urutan temporer dengan menggunakan koefisien 
jalur sebagai besaran nilai dalam menentukan besarnya pengaruh variabel independen exogenus terhadap variabel dependen endogenus. Hasil analisis jalur disajikan pada tabel 2 .

Tabel 2. Hasil Path Analysis

\begin{tabular}{|c|c|c|c|c|}
\hline \multicolumn{2}{|c|}{ Standarized } & \multirow{2}{*}{ Sig } & \multirow{2}{*}{ A } & \multirow{2}{*}{ Keterangan } \\
\hline Jalur & Beta & & & \\
\hline $\mathrm{X} 1 \longrightarrow \mathrm{Z}$ & 0,584 & 0,000 & 0,05 & Signifikan \\
\hline $\mathrm{X} 2 \longrightarrow \mathrm{Z}$ & 0,237 & 0,035 & 0,05 & Signifikan \\
\hline $\mathrm{X} 1 \longrightarrow \mathrm{Y}$ & 0,314 & 0,017 & 0,05 & Signifikan \\
\hline $\mathrm{X} 2 \longrightarrow \mathrm{Y}$ & 0,313 & 0,002 & 0,05 & Signifikan \\
\hline $\mathrm{Z} \longrightarrow \mathrm{Y}$ & 0,366 & 0,005 & 0,05 & Signifikan \\
\hline
\end{tabular}

Sumber : Data Diolah.

Berdasarkan Tabel 2 untuk menganalisis jalur pertama dapat dijelaskan bahwa antara Kepemimpinan Transformasional (X1) dengan Keput Komitmen Organisasi (Z) memiliki pengaruh yang signifikan. Hal tersebut dapat diketahui dengan hasil nilai signifikan yaitu 0,000 lebih kecil dari $\alpha=0,05$. Jalur kedua antara Lingkungan Kerja (X2) dengan Komitmen Organisasi (Z) memiliki pengaruh yang signifikan yaitu sebesar 0,035 lebih kecil dari $\alpha=0,05$. Jalur ketiga antara Kepemimpinan Transformasional (X1) dengan Semangat Kerja (Y) memiliki pengaruh yang signifikan yaitu sebesar 0,017 lebih kecil dari $\alpha=0,05$. Jalur keempat antara Lingkungan Kerja (X2) dengan Semangat Kerja (Y) memiliki pengaruh yang signifikan sebesar 0,002 yaitu lebih kecil dari $\alpha=0,05$. Jalur kelima antara Komitmen Organisasi (Z) dengan Kepuasan Pelanggan (Y) memiliki pengaruh yang signifikan yaitu sebesar 0,005 . Hasil analisis jalur dapat dilihat pada gambar 1 .

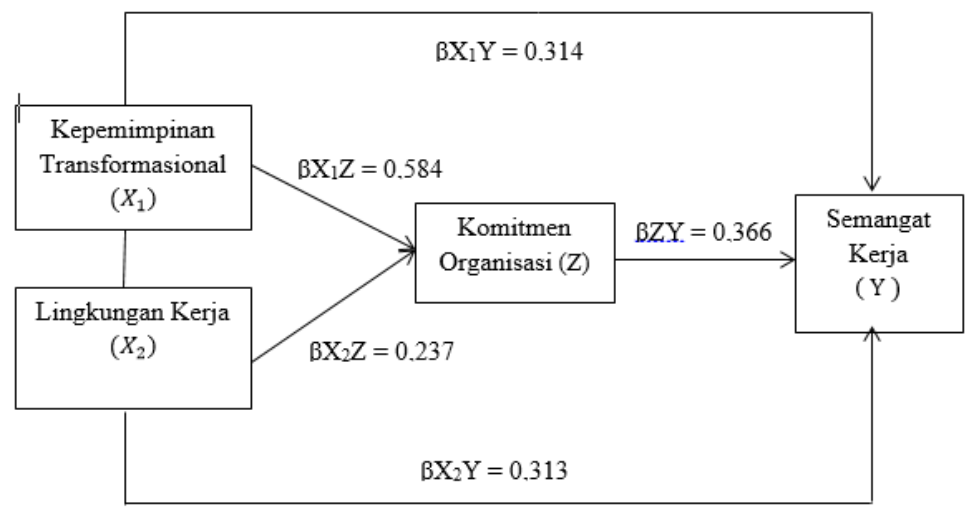

Gambar 1. Model Analisis Jalur

Koefisien jalur dihitung dengan membuat persamaan struktutal yaitu persamaan regresi yang menunjukkan hubungan. Model analisis jalur dalam persamaan adalah sebagai berikut:

Koefisien jalur dihitung dengan membuat persamaan struktutal yaitu persamaan regresi yang menunjukkan hubungan. Model analisis jalur dalam persamaan berikut ini.

$$
\begin{aligned}
& \mathrm{Z}=0,584 \mathrm{X} 1 \mathrm{Z}+0,237 \mathrm{X} 2 \mathrm{Z}+e \ldots \ldots \ldots \ldots \ldots \ldots \ldots \ldots \ldots \ldots .(\text { Persamaan } 1) \\
& \mathrm{Y}=0,314 \mathrm{X} 1 \mathrm{Y}+0,313 \mathrm{X} 2 \mathrm{Y}+0,366 \mathrm{Y} \mathrm{Y}+e \ldots \ldots \ldots \ldots \ldots \ldots(\text { Persamaan } 2)
\end{aligned}
$$


Uji t digunakan untuk melihat signifikasi secara parsial dari masing-masing variabel bebas terhadap variabel terikat, level yang digunakan $\alpha=5 \%$. Hasil uji $\mathrm{t}$ disajikan pada tabel 3 .

Tabel 3. Hasil Uji t

\begin{tabular}{cc}
\hline Variabel & Sig \\
\hline $\mathrm{X} 1 \longrightarrow \mathrm{Z}$ & 0,000 \\
$\mathrm{X} 2 \longrightarrow \mathrm{Z}$ & 0,035 \\
$\mathrm{X} 1 \longrightarrow \mathrm{Y}$ & 0,017 \\
$\mathrm{X} 2 \longrightarrow \mathrm{Y}$ & 0,002 \\
$\mathrm{Z} \longrightarrow \mathrm{Y}$ & 0,005 \\
\hline
\end{tabular}

Sumber:Data Diolah.

Berdasarkan Tabel 3. tersebut dapat diketahui besar dari pengaruh masing-masing variabel independen terhadap variabel dependen sebagai berikut:

1. Kepemimpinan Transformasional (X1) terhadap variabel Komitmen Organisasi (Z) Berdasarkan Tabel 4.16 dapat dilihat bahwa Tingkat signifikansi $(\alpha)$ dari variabel Kepemimpinan Transformasional (X1) adalah $0,000<0,05$. Hal ini berarti Kepemimpinan Transformasional berpengaruh signifikan terhadap Komitmen Organisasi (H1 diterima).

2. $\quad$ Lingkungan Kerja (X2) terhadap variabel Komitmen Organisasi (Z)

Berdasarkan Tabel 4.16 dapat dilihat bahwa Tingkat signifikansi $(\alpha)$ dari variabel Lingkungan Kerja $\left(\mathrm{X}_{2}\right)$ adalah $0,035<0,05$. Hal ini berarti Lingkungan Kerja berpengaruh signifikan terhadap Komitmen Organisasi ( $\mathrm{H} 2$ diterima)

3. Kepemimpinan Transformasional (X1) terhadap variabel Semangat Kerja (Y)

Berdasarkan Tabel 4.16 dapat dilihat bahwa Tingkat signifikansi $(\alpha)$ dari variabel Kepemimpinan Transformasional (X1) adalah 0,017 <0,05. Hal ini berarti Kepemimpinan Transformasional berpengaruh signifikan terhadap Semangat Kerja (H3 diterima).

4. Lingkungan Kerja (X2) terhadap variabel Semangat Kerja (Y)

Berdasarkan Tabel 4.16 dapat dilihat bahwa Tingkat signifikansi $(\alpha)$ dari variabel Lingkungan Kerja (X2) adalah 0,002 <0,05. Hal ini berarti Lingkungan Kerja berpengaruh signifikan terhadap Semangat Kerja (H4 diterima).

5. Komitmen Organisasi (Z) terhadap variabel Semangat Kerja (Y)

Berdasarkan Tabel 4.16 dapat dilihat bahwa Tingkat signifikansi $(\alpha)$ dari variabel Komitmen Organisasi $(\mathrm{Z})$ adalah $0,005<0,05$. Hal ini berarti Komitmen Organisasi berpengaruh signifikan terhadap Semangat Kerja (H5 diterima).

\section{Pembahasan}

\section{Pengaruh Kepemimpinan Transformasional Terhadap Komitmen Organisasi}

Hasil analisis regresi berganda pada Uji t terhadap hipotesis pertama $(\mathrm{H} 1)$ menunjukkan bahwa Kepemimpinan Transformasional berpengaruh terhadap Komitmen Organisasi dengan melihat taraf signifikansinya yaitu sebesar 0,000. Hubungan yang ditunjukkan oleh koefisien regresi adalah positif artinya semakin baik Kepemimpinan Transformasional maka Komitmen Organisasi akan semakin meningkat (H1 diterima).

Menurut Robbins dan Judge (2015) kepemimpinan transformasional merupakan model kepemimpinan yang mana para pemimpin menginspirasi para pengikutnya untuk melampaui kepentingan diri mereka sendiri dan yang berkemampuan untuk memiiki pengaruh secara mendalam dan luar biasa terhadap para pengikutnya. Sedangkan 
komitmen organisasi menurut Suparyadi (2015) komitmen organisasi sebagai derajat di mana karyawan percaya dan mau menerima tujuan-tujuan organisasi dan akan tetap atau tidak akan meninggalkan organisasinya. Komitmen organisasional akan membuat pekerja memberikan yang terbaik kepada organisasi tempat dia bekerja. Pekerja dengan komitmen yang tinggi akan lebih berorientasi pada kerja. Pekerja yang memiliki komitmen organisasional tinggi akan cenderung senang membantu dan dapat bekerjasama (Kesuma dan Supartha: 2016).

Hasil penelitian ini sejalan dengan penelitian sebelumnya yang dilakukan oleh Kesuma dan Supartha (2016) yang menyatakan bahwa terdapat pengaruh yang signifikan dari Kepemimpinan Transformasional terhadap Komitmen Organisasi. Jadi dapat disimpulkan Kepemimpinan Transformasional berpengaruh terhadap Komitmen Organisasi Usaha Tape di Kabupaten Bondowoso.

\section{Pengaruh Lingkungan Kerja Terhadap Komitmen Organisasi}

Hasil analisis regresi berganda pada Uji t terhadap hipotesis kedua $\left(\mathrm{H}_{2}\right)$ menunjukkan bahwa Lingkungan Kerja berpengaruh terhadap Komitmen Organisasi dengan melihat taraf signifikansinya yaitu sebesar 0,035. Hubungan yang ditunjukkan oleh koefisien regresi adalah positif artinya semakin tinggi Lingkungan Kerja maka Komitmen Organisasi akan semakin meningkat ( $\mathrm{H}_{2}$ diterima).

Nitisemito (2014) mengemukakan "lingkungan kerja adalah segala sesuatu yang ada disekitar para pekerja yang dapat mempengaruhi dirinya dalam menjalankan tugastugas yang diembankan." Lingkungan kerja mencerminkan kondisi internal suatu organisasi karena lingkungan kerja hanya dapat dirasakan oleh anggota organisasi tersebut, dan dapat menjadi sarana untuk mencari penyebab perilaku negatif yang muncul pada karyawan (Salahudin; 2013). Menurut Mangkunegara (2008) komitmen kerja seorang karyawan merupakan kondisi atau energi yang menggerakkan diri karyawan yang terarah atau tertuju untuk tujuan organisasi perusahaan. Komitmen organisasional ikut dipengaruhi oleh lingkungan tempat seorang karyawan bekerja. Jika lingkungan kerja tersebut kurang menunjang, misalnya fasilitas kurang, hubungan kerja kurang harmonis, jaminan sosial dan keamanan kurang, maka secara otomatis komitmen karyawan terhadap organisasi menjadi makin luntur (Kuntjoro, 2009).

Hasil penelitian ini sejalan dengan penelitian sebelumnya yang dilakukan oleh Salahudin (2013) yang menyatakan bahwa terdapat pengaruh yang signifikan dari Lingkungan Kerja terhadap Komitmen Organisasi. Jadi dapat disimpulkan Lingkungan Kerja berpengaruh terhadap Komitmen Organisasi Usaha Tape di Kabupaten Bondowoso.

\section{Pengaruh Kepemimpinan Transformasional Terhadap Semangat Kerja}

Hasil analisis regresi berganda pada Uji t terhadap hipotesis pertama (H1) menunjukkan bahwa Kepemimpinan Transformasional berpengaruh terhadap Semangat Kerja dengan melihat taraf signifikansinya yaitu sebesar 0,017. Hubungan yang ditunjukkan oleh koefisien regresi adalah positif artinya semakin baik Kepemimpinan Transformasional maka Semangat Kerja akan semakin meningkat (H3 diterima).

Menurut Yukl (2010) kepemimpinan transformasional sebagai sebuah proses yang padanya para pemimpin dan pengikut saling menaikkan diri ketingkat moralitas dan motivasi yang lebih tinggi. Pemimpin tersebut memotivasi para pengikut dengan cara membuat mereka lebih sadar mementingkan organisasi atau tim daripada kepentingan diri sendiri. Menurut Hasibuan (2013) mengemukakan bahwa semangat kerja adalah 
keinginan dan kesungguhan seorang mengerjakan pekerjaannya dengan baik serta berdisiplin untuk mencapai produktivitas yang maksimal.

Hasil penelitian ini sejalan dengan penelitian sebelumnya yang dilakukan oleh Larasati (2014) yang menyatakan bahwa terdapat pengaruh yang signifikan dari Kepemimpinan Transformasional terhadap Semangat Kerja. Jadi dapat disimpulkan Kepemimpinan Transformasional berpengaruh terhadap Semangat Kerja Usaha Tape di Kabupaten Bondowoso.

\section{Pengaruh Lingkungan Kerja Terhadap Semangat Kerja}

Hasil analisis regresi berganda pada Uji t terhadap hipotesis kedua $\left(\mathrm{H}_{2}\right)$ menunjukkan bahwa Lingkungan Kerja berpengaruh terhadap Semangat Kerja dengan melihat taraf signifikansinya yaitu sebesar 0,002. Hubungan yang ditunjukkan oleh koefisien regresi adalah positif artinya semakin tinggi Lingkungan Kerja maka Semangat Kerja akan semakin meningkat (H4 diterima).

Sihombing (2004) menyatakan bahwa "lingkungan kerja adalah faktor-faktor di luar manusia baik fisik maupun no-fisik dalam suatu organisasi". Faktor fisik ini mencakup peralatan kerja, suhu tempat kerja, kesesakan dan kepadatan, kebisingan, luas ruang kerja sedangkan non-fisik mencakup hubungan kerja yang terbentuk di instasi antara atasan dan bawahan serta antara sesama karyawan. Menurut Azwar (2011) semangat kerja merupakan gambaran perasaan yang berhubungan dengan tabiat atau jiwa semangat kelompok, kegembiraan atau kegiatan, untuk kelompok-kelompok pekerja yang menunjukkan iklim dan suasana pekerja.

Hasil penelitian ini sejalan dengan penelitian sebelumnya yang dilakukan oleh Tamara (2016) yang menyatakan bahwa terdapat pengaruh yang signifikan dari Lingkungan Kerja terhadap Semangat Kerja. Jadi dapat disimpulkan Lingkungan Kerja berpengaruh terhadap Semangat Kerja Usaha Tape di Kabupaten Bondowoso.

\section{Pengaruh Komitmen Organisasi Terhadap Semangat Kerja}

Hasil analisis regresi berganda pada Uji t terhadap hipotesis ketiga (H3) menunjukkan bahwa Komitmen Organisasi berpengaruh terhadap Semangat Kerja dengan melihat taraf signifikansinya yaitu sebesar 0,005. Hubungan yang ditunjukkan oleh koefisien regresi adalah positif artinya semakin tinggi Komitmen Organisasi maka Semangat Kerja akan semakin meningkat (H5 diterima).

Menurut Mangkunegara (2008) komitmen kerja seorang karyawan merupakan kondisi atau energi yang menggerakkan diri karyawan yang terarah atau tertuju untuk tujuan organisasi perusahaan. Menurut Nitisemito (2014) semangat kerja adalah melakukan pekerjaan lebih giat sehingga dengan demikian pekerjaannya akan lebih dapat diharapkan selesai lebih cepat dan lebih baik.

Hasil penelitian ini sejalan dengan penelitian sebelumnya yang dilakukan oleh Fane (2016) yang menyatakan bahwa terdapat pengaruh yang signifikan dari Komitmen Organisasi terhadap Semangat Kerja. Jadi dapat disimpulkan Komitmen Organisasi berpengaruh terhadap Semangat Kerja Usaha Tape di Kabupaten Bondowoso. 


\section{KESIMPULAN}

Hasil pengujian regresi berganda atas pengaruh Kepemimpinan Transformasional terhadap Komitmen Organisasi menunjukkan hubungan yang positif signifikan. Ini membuktikan bahwa Kepemimpinan Transformasional yang baik akan meningkatkan Komitmen Organisasi. Hasil pengujian regresi berganda atas pengaruh Lingkungan Kerja terhadap Komitmen Organisasi menunjukkan hubungan yang positif signifikan. Ini membuktikan bahwa Lingkungan Kerja yang baik akan meningkatkan Komitmen Organisasi. Hasil pengujian regresi berganda atas pengaruh Kepemimpinan Transformasional terhadap Semangat Kerja menunjukkan hubungan yang positif signifikan. Ini membuktikan bahwa Kepemimpinan Transformasional yang baik akan meningkatkan Semangat Kerja. Hasil pengujian regresi berganda atas pengaruh Lingkungan Kerja terhadap Semangat Kerja menunjukkan hubungan yang positif signifikan. Ini membuktikan bahwa Lingkungan Kerja yang baik akan meningkatkan Semangat Kerja. Hasil pengujian regresi berganda atas pengaruh Komitmen Organisasi terhadap Semangat Kerja menunjukkan hubungan yang positif signifikan. Ini membuktikan bahwa Komitmen Organisasi yang sesuai akan meningkatkan Semangat Kerja.

\section{DAFTAR PUSTAKA}

Azwar, S. 2011. Sikap dan Perilaku Dalam: Sikap Manusia Teori dan Pengukurannya Yogyakarta: Pustaka Pelajar.

Danim, Sudarwan. 2004. Motivasi Kepemimpinan dan Efektivitas Kelompok. PT Remaja Rosdakarya. Bandung.

Fane, Sugeng Mianto. 2016. Pengaruh Komitmen Organsiasi dan Motivasi Kerja Terhadap Semangat Kerja Karyawan CV. Tunas Pratama Palembang. Jurnal Manajemen. Vol. 4 No. 3 Juli 2016. ISSN: $2089-6832$.

Galih dan Azis, 2017. Analisis Pengaruh Gaya Kepemimpinan dan Motivasi Kerja Terhadap Kinerja Pegawai Pada Dinas Tenaga Kerja Propinsi Lampung, Staff Pengajar Jurusan Administrasi Negara. Universitas Bandar Lampung.

Hasibuan, Malayu. 2013. Manajemen Sumber Daya Manusia. Jakarta: PT Bumi Aksar. Hermawan, Asep. 2009. Penelitian Bisnis. Jakarta : PT. Grasindo.

Kesuma dan Supartha. 2016. Pengaruh Kepemimpinan Transformasional terhadap Komitmen Organisasional dengan Mediasi Organizational Citizenship Behavior dan Kepuasan Kerja. Universitas Udayana, Bali

Kuntjoro, Mudrajad. 2009. Metode Riset Untuk Bisnis \& Ekonomi. Penerbit. Erlangga. Jakarta.

Larasati. 2014. Pengaruh Motivasi Kerja Terhadap Semangat Kerja Karyawan Wilayah Telkom Jabar Barat Utara. Jurnal Manajemen Dan Organisasi, 5(3), 200-213. 
Mangkunegara, Anwar. 2008. Manajemen Sumber Daya Manusia. Remaja Rosdakarya, Bandung.

Mardani. 2013. Pengaruh Kepemimpinan, Motivasi, KepuasanKerja terhadap Komitmen Organisasional dan Kinerja Karyawan pada Karyawan PT.Smartfren,tbk di Surabaya. Universitas Airlangga.

Mardiana. 2005. Manajemen Produksi. Penerbit Badan Penerbit IPWI. Jakarta.

Nitisemito, 2014. Manajemen Personalia. Ghalia Indonesia. Jakarta.

Robbins dan Judge, 2015. Perilaku Organisasi. Buku 2, Jakarta : Salemba Empat.

Salahudin. 2013. Pengaruh Kompensasi Dan Budaya Organisasi Terhadap Kinerja Pegawai Dengan Motivasi Kerja Sebagai Variabel Perantara. Universitas Tanjungpura. Pontianak

Sarwono, Jonathan dan Budiono Herlina. 2012. Statistik Terapan Aplikasi untuk Riset Skripsi, Tesis, dan Disertasi menggunakan SPSS, AMOS dan Excel. Jakarta : PT. Elex Media Komputindo-Kompas Gramedia.

Sihombing, Umberto. 2004. Pengaruh Keterlibatan Dalam Pengambilan Keputusan, Penilaian pada Lingkungan Kerja dan Motivasi Berprestasi Terhadap Kepuasan Kerja Pamong Praja. http://www.dupdiknas.go.ig.

Sugiyono. 2009. Metode Penelitian Kuantitatif dan Kualitatif. Bandung: Alfabeta.

Suparyadi. 2015. Manajemen Sumber Daya Manusia, Menciptakan Keunggulan Bersaing Berbasis Kompetisi SDM. Jakarta: Andi.

Tamara, 2016. Pengaruh Kepuasan Kerja Terhadap Kinerja Karyawan Melalui Motivasi Kerja Pada CV. Union Event Planner. Universitas Kristen Petra. Surabaya.

Yukl, Gary. 2010. Kepemimpinan dalam Organisasi, Edisi Kelima. Jakarta: PT. Indeks. 